\title{
A „TANÍTSUNK MAGYARORSZÁGÉRT MENTORPROGRAM” ELŐKÉSZÍTŐ KURZUSÁN RÉSZTVEVŐ MENTORJELÖLTEK MOTIVÁCIÓI
}

\author{
Szerző: \\ Godó Katalin \\ Debreceni Egyetem (Magyarország) \\ Neveléstudományi Doktori Program \\ E-mail cím: \\ katalin1en@gmail.com
}

\author{
Lektorok: \\ Ceglédi Tímea (PhD) \\ Debreceni Egyetem (Magyarország) \\ Iványi Zsuzsanna $(\mathrm{PhD})$ \\ Debreceni Egyetem (Magyarország) \\ ...és további két anonim lektor
}

Godó Katalin (2021). A „Tanítsunk Magyarországért Mentorporgram” előkészítő kurzusán résztvevő mentorjelöltek motivációi. Különleges Bánásmód, 7. (2). 21-41. DOI 10.18458/KB.2021.2.21

\begin{abstract}
Absztrakt
Jelen tanulmány a mentorálás oktatásban betöltött szerepére fókuszál. A téma az utóbbi években egyre inkább a kutatók látószögébe került (Bencsik és Juhász, 2017). A nemzetközi gyakorlattal összhangban a hazai köznevelési intézményekben is felértékelődött a mentorok szerepe, az egyes iskolatípusokban pedig különböző mentorprogramok jelentek meg. Kutatásunkban a Tanitsunk Magyarországért Mentorprogram debreceni hallgatóit vizsgáltuk, hogy feltérképezzük az egyetemista mentorjelöltek motivációinak aspektusait, a mentoráláshoz kapcsolódó érzelmi és kognitív viszonyaikat, a mentorálás iránti elkötelezettségüket (vagy annak hiányát). További célunk volt annak feltárása, hogy mi minden be folyásolja a mentorrá válás végső döntését a hallgatók körében (anyagi, mentális erőforrás stb.), s ezek a tényezők milyen kölcsönhatásban vannak egymással. Kutatásunkat 151 fơvel végeztük azok között az egyetemista fiatalok között, akik a mentorrá válás elméleti kurzusán részt vettek a 2018/2019-es tanév tavaszi félévében. Kvantitatív kutatásunk alapjait a TM1 kurzus oktatói, Ceglédi, Engler, Szűcs, Hüse és Berényi (2019) által létrehozott és lekérdezett kérdőív adja, melyet 2019/20-as tanév elején töltöttek ki a kurzusra jelentkezett hallgatók. A kitöltők közel 50\%-a döntött úgy végül, hogy elkötelezi magát a mentorálás mellett, s a másik 50\%-a pedig valamilyen oknál fogva mégsem vállalt mentori tevékenységet. Eredményeink alapján elmondható, hogy a mentorok számára a segítségnyújtás és az ösztöndíj formájában kapott anyagi juttatás jelentették a fő motivációs faktorokat, azonban utóbbi elsősorban a férfi hallgatók számára volt fontos, valamint az anyagi aspektus a hátrányos helyzetú hallgatók számára sem volt elsődleges a motiváció alakulásában. Következtetéseink szerint a mentorálásban az erôs belső motiváció és elkötelezettség játszik fontos szerepet, míg a külső motivációként megjelenő anyagi juttatás másodlagos lehet, de szintén fontos.
\end{abstract}

Kulcsszavak: egyetemista mentor, mentori kapcsolat, mentorálás, interperszonális kapcsolat, mentori motiváció

Diszciplina: neveléstudomány, nevelésszociológia 


\section{Abstract \\ MOTIVATIONS OF MENTOR CANDIDATES PARTICIPATING IN THE LET'S TEACH FOR HUNGARY MENTOR PROGRAM'S PREPARATION COURSE}

The present study focuses on the role of mentoring in education. The topic of mentoring has increasingly got into the focus of researchers in recent years (Bencsik és Juhász, 2017).In accordance with international practice, the role of mentors in Hungarian public education institutions has become more valuable. In proportion to recognizing its role in education, different mentoring programs have emerged in each type of school. In the present study, our orientation is specifically aimed at the students of the Teach for Hungary Mentoring Program in Debrecen, in order to map the aspects of the motivations of the student mentor candidates in Debrecen. Among other things, we are curious about their emotional and cognitive attitude toward mentoring, and we are interested in the extent (or lack thereof) of their commitment to mentoring. Our aim is to explore, what influences the final decision among students to become a mentor (material, mental resource, etc.) and how these factors interact/relate to each other. In the spring semester of the 2018/2019 academic year, we conducted our research with 151 young students who took part in a theoretical course to become a mentor. The foundation of our research is the questionnaire created by Ceglédi, Szúcs, Hüse, and Berényi (2019), and that form was filled in by a student who applied for a TMO1 course at the beginning of the 2019/20 academic year. Nearly $50 \%$ of respondents decided to commit themselves to mentoring, and the other $50 \%$ did not undertake mentoral activity for some reason. Based on our results, it can be said that assistance and financial support in the form of scholarship were the main motivating factors for mentors, but the latter was important mainly for male students, nor had the financial aspect primary importance for students with a disadvantaged background in the development of motivation. According to our conclusions, commitment and strong internal motivations play an important role in mentoring, while financial benefits in the form of external motivation can be secondary, but also play an important role in motivation.

Keywords: university student mentor, mentoring relationship, interpersonal relationship, motivational factors in mentoring

Disciplines: educational science, sociology of education

\section{Bevezetés}

A mentorálás alig pár évtizede került hazánkban is a tudományos érdeklődés horizontjába. Elsősorban leginkább a menedzsmenttel, vállalatfejlesztéssel kapcsolatos vizsgálatok köré épülő mentorfogalom volt jellemző (Bencsik és Juhász, 2017). Az utóbbi időkben viszont szélesebb körben is elterjedt a mentorálás fogalmának használata, s az oktatásban is felismerték annak kulcsfontosságú szerepét (Perjés és Héjja-Nagy, 2018). Mind külföldi, mind hazai viszonylatban is egyre inkább növekszik az iskolai keretek között létrejövő mentorprogramoknak a száma (Raufelder és Ittel, 2012). Tanulmányunk a pedagógusi tevékenységgel összhangban múködő, azt kiegészítő tanulói mentorálással foglalkozik.

Kutatásunk arra fókuszál, hogy mi motiválja az egyetemistákat arra, hogy részt vegyenek a mentori tevékenységben. Kíváncsiak vagyunk arra, hogy vajon mennyire érett meg a mentorrá válás bizonyosságának ténye azelőtt a mentorjelöltekben, hogy valaki kipróbálta volna magát ebben a szerepeben. Kitérünk arra, hogy az anyagi haszonszerzés mellett/vagy helyett $\mathrm{mi}$ az, ami miatt 
preferálják a mentorálást; egyéni vagy társadalmi célok vezérlik-e a mentorokat elsősorban. Megvizsgáljuk, hogy a külső és belsô motivációs tényezők milyen mértékben kerülnek előtérbe. Mint ahogy a hallgatók is sokfélék lehetnek (eltérô szakkal, karral, életkorral bírnak), a motivációjuk is széles skálán mozoghat. A program sikerességének egyik kulcstényezője, hogy feltérképezzük a mentorok motivációját és elkötelezettségük mértékét. Ezért még a mentorálás megkezdése előtt bementi mérést végeztünk. Szó lesz többek között a mentorok képzési rekrutációs bázisáról, a szülők iskolai végzettségérôl, továbbá a motiváció nemi különbségeiről is. Különös tekintettel arra, hogy egy pilot programról van szó, eredményeink fontos visszajelzést jelenthetnek a program koordinátorai, oktatói felé. A Tanítsunk Magyarországért mentorprogram vizsgálatának nagyon kevés hazai előzménye van, így a kutatás során kapott empirikus eredmények jelentősen hozzájárulhatnak a program további fejlesztéséhez.

\section{A mentorálás típusai a szakirodalom alapján}

A mentorálás alapvetô definíciója az életkori sajátosságokon/különbözőségen alapul. Russel és Adams (1997) szerint a mentorálás személyek között lezajló folyamat, azaz olyan interperszonális kapcsolat, amely egy szenior (idős), tapasztalt kolléga és egy junior (fiatal) között megy végbe. A szakirodalom alapján ezt hívjuk más néven ifjúsági mentorálásnak (Kállai, 2015). Azonban előfordulhat, hogy a fiatalok mentorálják az időseket (pl. az új technológiák megismertetése esetén), ami már a fordított (vagy más néven: ellentétes) mentorálás jelensége (Bencsik és Juhász, 2017).

A mentorálás egyes típusait nemcsak a résztvevők életkora alapján lehet megkülönböztetni. Ceglédi és mtsi. (2020) kutatásukban laikus és professzionális csoportokra osztják a mentorokat attól függően, hogy részesültek-e előzetes ismeretszerzésben a mentorálást illetően. A mentorálás éppen attól nevezhető professzionális tevékenységnek, hogy tanulható, fejleszthető (Ceglédi és tsi, 2019). Feltétele a kognitív érettség mellett a lelki érettség is. Előfordul továbbá, hogy az egyén környezetében olyan segítők vannak jelen, akiknek a támogatása rokonítható a mentori tevékenységgel. Ök a laikus mentorok, akik egyben „névtelen” mentorok, mivel legtöbbször nincsenek mentorként megjelölve.

Alapvetően kétféle típusú segítést hangsúlyoz Kram (1985), melyet a mentor tud mentoráltjának adni: egyik ilyen a karrier típusú pártfogás/támogatás, a másik pedig a pszicho-szociális támogatás (K. Nagy, 2015). Ideális esetben mindkettő együttesen érvényesül a mentorálás során előbbi esetben a tanulmányi/iskolai karriert érintő kérdésekben áll rendelkezésre a mentor. Utóbbi kategóriába tartozik a megerősítés, motiválás, bátorítás stb., melyek a mentori szerepkör szerves részei - úgy is fogalmazhatnánk, hogy a mentor személyiségéből és kompetenciájából adódó többlethozam. Az érintettek pszicho-szociális szükségleteire való reakciója a mentornak legalább annyira fontos (ha nem fontosabb), mint az információs közvetítés, illetve a tanulmányi karrier szubvenciója. A mentorálás eredményessége nagymértékben függ ugyanis attól, hogy ezt a kétfajta típusú támogatást milyen arányban, összhangban képes megvalósítani a mentor.

A mentorálásnak illeszkednie kell továbbá a gyermek egyéni sajátosságaihoz (életkor stb.), szükségleteihez (kommunikáció stb.) (Bander és tsi, 2015), éppen ezért különösen fontos a mentoráltak egyén-specifikus, érzékeny megközelítése. Úgy véljük, akkor tudja igazán az egyénekben rejlő potenciált kiaknázni a mentor, ha személyre tudja szabni magát a mentorálást egy tudatosan irányított folyamat keretén belül. A program fóként, de nem meghatározott jelleggel a csoportos mentorálást preferálja (1 mentor 3-5 fó mentoráltat kap), amin belül mégis fontos a mentornak a diákokra való személyes orientációja, differenciálása is. A Be a Mentor (2006) útmutatója alapján a fiatalok 
esetében az érzelmeket kifejező/megfogalmazó beszélgetések egyfajta „biztonsági szelepként” is értelmezhetőek, mely alapján a mentoráltak ki tudják engedni magukból a pozitív és negatív érzéseket (mint egy szelep) (Bander és tsi, 2015). Egyes értelmezések szerint a mentorálás elsődleges célja a nevelés (Ehigie és tsi, 2011), ugyanis a mentor akarva-akaratlanul is szemléletet alakít és/vagy módosít, illetve személyiséget formál (lásd: később). A nevelés is egy értékközvetítő, értékrendszert kialakító, fejlesztő hatású bipoláris folyamat, amelynek fontos célja az, hogy ,az egyént életfeladatai megoldására képessé tegye" (Gaál és Jászi, 2016). A mentorálás nevelés jellegú szemléletét hangsúlyozza Rhodes (2002) is, miszerint „a mentori a kapcsolatban az idősebb (..) elősegíti a fiatal személy átlépését a felnőttkorba". Fontos feladata a mentornak a mentorált autonómiájának elősegítése, mely megkönnyíti a mentorról való leválás folyamatát (Bencsik és Juhász, 2017). A mentorálásban ugyanis éppen az a lényege, hogy megszúnjön, azaz, hogy egy idő után ne legyen szükség rá. Éppen ezért a mentorálás egy időszakos folyamat (adott időtartamra szól), nem egész életen át tart. A mentorálás hatása viszont a mentor jelenléte nélkül, a jövőben attól még kamatozik.

Összességében elmondhatjuk, hogy a mentorálás gyakorlatától nem állnak távol a pedagógiai gyakorlatra jellemző kompetenciák (Kovács és tsi., 2015), sôt az oktatókkal jól korreláló, jól harmonizáló gyakorlatról van szó, mely pozitív hatással lehet a diák egyéni iskolai karrierjére. A fejlődésorientált, motiváció-serkentő intézményi klíma légkörébe is jól beintegrálható maga a mentorálás.

A mento-rálást nevezhetjük éppen ezért olyan extrakurrikuláris (tanórán kívüli) tevékenységnek, mely a tanári munkát kiegészíti, sôt globális értelemben véve szervezeti szinten az iskola egészére nézve pozitív hatást gyakorolhatnak a mentorprogramok. Az egyéni szintű fejlődés a rendszerszintű fejlődést is előmozdíthatja, hiszen az oktatási intézmény tagjaitól nagymértékben függhet az adott iskola minőségi besorolása/osztályozása.

\section{Mentori metaforák}

Az Idegen Szavak szótárában a mentor kifejezés úgy jelenik meg, miszerint a mentor 'idősebb tanácsadó, pártfogó, atyai jóbarát' (Juhász, 2009). Ennek a meghatározásnak alapját jelenti az is, hogy Mentor egy ókori bölcs aggastyán volt (megjegyzés: Homérosz Odüsszeia c. eposzában Odüsszeusz a trójai háború idején fiát, Telemakhoszt Mentor pártfogására bízta, míg ő háborúzni volt -Bencsik és Bencsik, 2017), ami jól mutatja, hogy a mentorok tevékenységének hagyományos értelmezését sokáig a mentor és mentorált közötti nagy életkori különbség alapján határozták meg (lásd az előző fejezetben). Napjainkban azonban a mentori tevékenység meghatározása már nagyobb sokszínúséget mutat. A fogalom árnyaltságát nem csak régen, de napjainkban is jól mutatják a mentor különféle megnevezései és ellen-megnevezései ( $\mathrm{mi} \mathrm{az}$, ami nem a mentor).

Fontos azonban megkülönböztetni, hogy a mentorálás nem áll távol a segítői hivatástól, ugyanis vele az egyén egy másik egyén javát szolgálja (tágabb értelemben véve pedig a közösségét). Ez a fajta hozzáállás a proszociális (segítő, a közösséget szem előtt tartó hozzáállás, viselkedés) magatartás egyik ismérve. Noha a mentor segítő ugyan, de nem „ápoló” (Kovács és Fáyné Dombi, 2015). A mentor nem veszi el az egyén felelősségét is a saját fejlődési folyamatában, sőt külön felhívja arra a figyelmet. Ô maga inkább kísérô, azonban mégsem barát (Kovács és Fáyné Dombi, 2015), ugyanis a mentori folyamatban résztvevők között a feltárulkozás mértéke aszimmetrikus. A mentor nem a mentorálttal osztja meg személyes jellegú, bizalmi belső kérdéseit. Továbbá a mentor nem pszic-hológus, noha meghallgat, de nem diagnosztizál (Kovácsné és Fáyné Dombi, 2015). A mentor iránymutatást ad, de „mégsem szüló vagy tanár, 
nem alakit ki függöségi és hierarchikus viszonyt” a mentorálttal (Kovácsné és Fáyné Dombi, 2015, 331.). A mentor az, aki egy darabig elkíséri a mentoráltat, de nem állandóan aktív a jelenléte az egyén életében, mindösszesen annak egy adott periódusában, időszakában. A mentor továbbá nem „pincér”, nem tálcán kínálja a kész megoldásokat, hanem tájékoztat a lehetőségekről és a diák önreflexív, perspektivikus gondolkodását segíti; továbbá azt, hogy ő maga legyen képes önmagáért való pozitív cselekvésre. A mentor nem irányító; a diáknak lehetőséget ad arra, hogy meghozza a saját döntéseit. Akaratát nem kényszeríti rá a mentoráltra. A mentor továbbá nem motivációs tréner, noha a diák motiválása fontos feladata, de nem csak és kizárólagos, pénzért folytatott tevékenysége.

A mai mentorfogalmat leginkább kifejezi az a hasonlat, miszerint a mentor egy útitárs, kísérő (Ceglédi és tsi, 2019). Ez a fajta megközelítés érzékelteti leginkább a partnerségen, együttmúködésen alapuló viszony lényegiségét, melynek fontos alapja az egymás iránti kölcsönös bizalom. Ez a meghatározás szintén rámutat arra, hogy napjainkban a mentor-mentorált kapcsolatnak már nem szükséges, kizárólagos feltétele a nagy életkori különbség, a mentor megjelenhet egyfajta nagytestvéri szerepben is, így kísérve a mentorált útját (Godó, 2021a: folyamatban lévő tanulmány).

\section{A motiváció fogalmának tisztázása}

A motiváció tulajdonképpen valamilyen cselekvésre történő mozgósítás, s ezt sugallja a kifejezés latin eredetű megfelelője/alapja is (movere jelentése: 'mozogni, mozgatni'). A motiváció valamiféle késztetésből fakad; vagyis az egyén viselkedésének hátterében valamilyen belső vagy külső erô áll, mely aktivitásra serkenti őt. A motivált embernek tehát van egy kívánt célállapot elérésére irányuló törekvése, melynek dinamikája a motiváció mértékétől függően alakul. Az emberek különböző szinteken, különböző módokon és különböző mértékben motiválhatók. Egyénfüggő a motiváció forrása is, mert nem mindenkinek ugyanaz jelent „húzóerőt”. Korosztályonként is változatos a motivációs bázisa az egyéneknek (gondoljunk a jutalmazás-büntetés módszerére), mint ahogy társadalmi szinten is másmás különbségek adódhatnak (késleltetett - azonnali motivációs jutalom).

A motiváció forrása alapján megkülönböztetünk külső, illetve belső motivációt. Az intrinzik motiváció lehet személyes növekedésre irányuló motiváció, tartalmas kapcsolatok kiépítésére vagy közösségi elköteleződésre irányuló törekvés, míg az extrinzik motiváció az a külső jutalmazással járó motivációt jelöl (hírnév, pénz, elismertség stb.). Különbséget lehet tenni ilyen szempontból a motiváció és a motiváltság fogalmai között. Az első esetben a motiváció kívülről ható ösztönzés valamilyen cél elérésére irányul, míg a motiváltság ezzel ellentétben az „egyénre jellemző belsővé vált tényezőként, tulajdonságként szabályozza cselekedeteinket” (Hegedűs, 2002). A belső motiváció esetében a tevékenység önmagában is jutalmazó az ember számára, a kívülről vezérelt motiváció esetében utólag jutalmazzák az egyént (pl. fizetéssel, díjjal stb.).

Kétfajta irányultsága lehet a motivációnak, motiváltságnak: a siker elérése vagy a kudarckerülés (pl. azért tanulok, hogy jó jegyet kapjak vagy azért, hogy ne kapjak egyest). Mindkét típusnak megvan a maga létjogosultsága, s egyénenként eltérő, hogy kiben melyiknek a reprezentációja érvényesül. A mentorrá válás esetén a sikerorientált megközelítés dominanciáját tartjuk azonban relevánsnak a mentor csatlakozásának saját motivációból eredő jellegéből kifolyólag. Gefferth (2014, szerk. idézi Bander és tsi, 2015) ugyanezt kihangsúlyozza a mentorált esetében is. Mi úgy véljük, hogy a mentorálás egy „közös megállapodáson nyugvó”, kölcsönösségen alapuló kapcsolat, melyben mindkét személy részvétele önkéntes alapú. Ez a fajta önkéntes jelleg pedig feltételezi a résztvevők 
valamilyen mértékủ, irányú motivációját. A tanulók motivációja és iskolai eredményessége pedig kölcsönösen képes egymásra hatni. Markos (2019) szerint a plusz, tanórai kereteken kívüli tevékenységek nemhogy elvonják a tanulót iskolától, hanem növelik az intézményi beágyazódását.

A motiváció kapcsán McCelland (1985) említést tesz teljesítménymotivációról, kompetencia- és kapcsolatmotivációról. A magas teljesítményszükségletű emberek a kihívást jelentő feladatként vállalnak bizonyos tevékenységeket. A kapcsolatmotivált emberek esetén a kapcsolatok létesítése az elsődleges. A kapcsolatmotiváció szoros összefüggésben lehet a kapcsolati tőke és a társadalmi tóke fogalmakkal is. A társadalmi tőke-elméletek ugyanis arra hívják fel a figyelmet, hogy a közösségi kapcsolatokban olyan erőforrás rejlik, mely lehetővé teszi bizonyos célok elérését a „közösségi transzmisszió" által (Coleman, 1994). Továbbá ezek a kapcsolatok olyan beruházások a humán tőkébe, melyből az egyén számára közvetlen haszon konfigurálható a tőkefelhalmozás (tőkeakkumuláció) által (Bourdieu, 1999). A kompetenciamotiváció White (1959) szerint az arra irányuló késztetése az egyénnek, hogy környezetével hatékony interakcióba lépjen, azaz hogy a tevékenysége révén ügyesnek, produktívnak érezze magát (Kő és tsi, 2017). Fontos ebben az esetben, hogy az egyén kompetensnek érezze magát végül valamiben.

\section{Alkalmasság-érzés}

A motivációt meghatározza továbbá a teljesítményre való alkalmasság is, így különösen fontos a kurzus végére, hogy a hallgatók mennyire érzik képesnek magukat arra, hogy vállalják a mentorrá válással járó kötelezettségeket (érzik-e magukban az ehhez szükséges képességeket, kompetenciákat stb.). Ennek alapján a mentori kurzusra való jelentkezés egyfajta preszuppozíciót is (előfeltevést) hordoz; mégpedig azt, hogy az egyetemista hallgatók, vagyis a mentorjelentkezők érzik magukban azt, hogy képesek lehetnek mentorrá válni.

A szociálpszichológiában ismert énhatékonyság fogalma is ide kapcsolható, mely az egyén hiedelmeit foglalja magában arra vonatkozóan, hogy ő maga képes olyan teljesítményt nyújtani, ami nagy mértékben befolyással lehet saját életét meghatározó eseményekre (Bandura, 1994). A magas énhatékonyságérzéssel rendelkező személyek a mentorálást kihívásként élik meg szemben az alacsony énhatékonysággal bíró személyekkel, akik esetén inkább elkerülő attitűd lesz jellemző. Sôt a mentorálás esetén nem csak az egyéni, hanem a kollektív hatékonyságról is lehet beszélni „csapat közös hiedelme, a képességeikben, hogy képesek kivitelezni viselkedések olyan sorozatát, ami bizonyos szintű eredményre vezet" (Bandura, 1997, 4.).

\section{A korai iskolaelhagyás elleni intézkedések, a Tanítsunk Magyarországért Mentorprogram bemutatása}

A korai iskolaelhagyás prevenciója a közoktatás fejlesztését célzó programok egyik fontos sarokköve. A Budapesti Intézet (2015) szerint a lemorzsolódás szakiskolai tanulók körében a legnagyobb, mely feltehetően nem független az általános iskolában gyökerező okoktól, például a helytelen iskolaválasztástól, szakválasztástól stb.). A korai iskolaelhagyás elkerülésének fontossága nemcsak hazánkban, hanem az Európai Unió szintjén is a szakpolitika fókuszába került. Az Európa 2020 stratégia „az oktatás terén ambiciózus célokat tűzött ki, például az iskolai lemorzsolódási arány 10\% alá csökkentését" (Európai Unió Alapjogi Ügynöksége, 2017).

Az elmúlt években azonban az figyelhető meg, hogy hazánkban a korai iskola-elhagyók száma növekedett, noha az uniós átlag-érték viszont csökkent (10,6\%) (Oktatási és Képzési Figyelő, 2019, 19.). 
A közoktatásból való lemorzsolódás kapcsán el- iskolaelhagyók aránya (Észak-Magyarország, mondható, hogy erőteljes összefüggésben áll a Észak-Alföld)(lásd: 1. ábra). Amint láthatjuk, a hátrányos helyzettel. Fehérvári Anikó (2015) korai iskolaelhagyás éppen a Tanítsunk Magyareredményei szerint a hátrányos helyzetủek által országért mentorprogram által lefedett térségekben lakott régiókban jelentősen magasabb a korai jelent kiemelt problémát (lásd: 2. ábra).

1. ábra: Korai iskolaelhagyók aránya Magyarországon régiók szerint, 2005-2014 (forrás: Fehérvári nyomán: Eurostat, 2005-2014, \%)

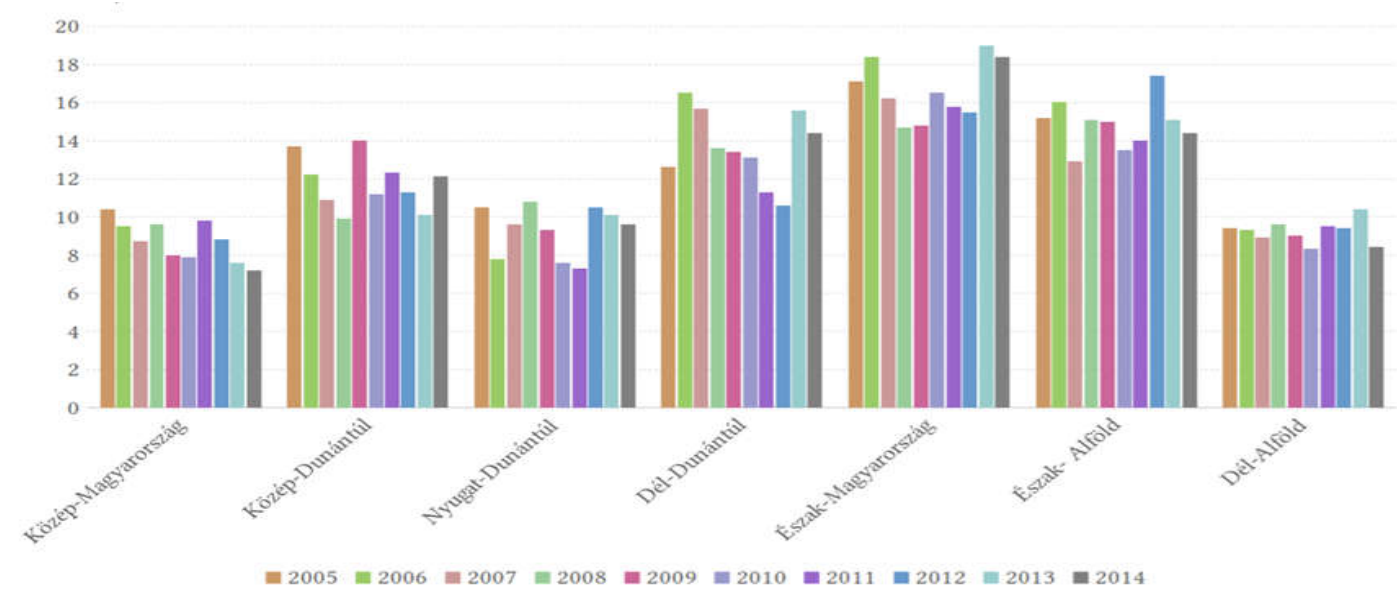

2. ábra: A Tanitsunk Magyarországért Mentorprogramba bevont alapfokú intéżmények (ISCED 2) $(n=70$ kistelepülés, 12 egyetemi város, forrás: tanitsunk. bu)

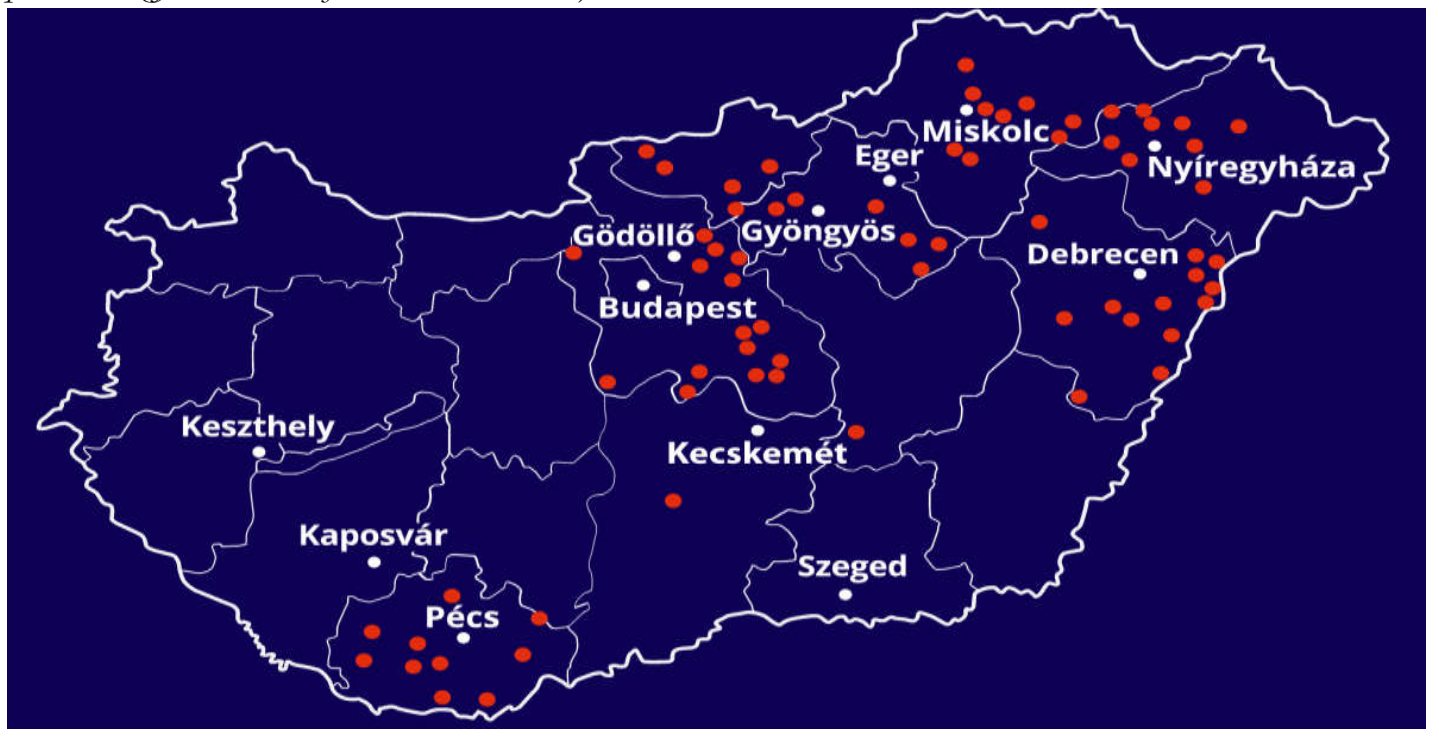


Kiemelt kérdés lehet, hogy hogyan támogathatjuk a közoktatásból való lemorzsolódás problémájának kezelésére vonatkozó nemzeti és uniós szintű törekvéseket a mentorprogramok segítségével.

A mentorok szerepe az általános is-kolák intézményeiben kiemelten jelentős lehet. Nem csak a célok megfogalmazása, konkretizálása, letisztázása nehézség a diákok körében, hanem az ezt követő további lépések sorozata is (hogyan jutok el az adott célig). Ez már önmagában komplex gondolkodást igényel (pl. a megfelelő iskola kiválasztása). Figyelembe kell hozzá venni az egyén „intencionális orientációit” (Pusztai, 2011. 9 o.), s az egyéni preferenciákon túl számos diákot jellemző személyiségjegyet, továbbá az iskolához való attitúdjét (szeret iskolába járni avagy sem), szubjektív viszonyát. Costa és Kallick (1993) szerint minden gyereknek és minden tanítónak szüksége van legalább egy olyan bizalmas személyre, aki provokatív kérdéseket tesz fel neki (idézi Kovács és Fáyné Dombi, 2015). Az előrevivő kérdések következtében tud a mentorált is proaktivizálódni.

A feladat összetettsége még a szülók számára is kihívásokkal teljes, nemhogy annak a tizenéves diáknak, aki az iskolapadban ül. Nem minden diák van egyaránt tisztában a döntés súlyával, várható hozamával. A mentor szerepe éppen ezért különösen meghatározó lehet ebben a pályaválasztást érintő szenzitív idôszakban. Sokak esetében a döntés az egész életpálya karriert meghatározza, azaz a döntés egyszeri jellege jellemző, sőt a döntést ők maguk különböző tényezôk, kényszerítő körülmények, hatások, beidegződések, családi és társadalmi elvárások miatt végesnek és megfordíthatatlannak (irreverzibilisnek) gondolják. Ezeknek a gondolatoknak a rendszerében segíthet a mentor rendet tenni.

Továbbá azt is szeretnénk kihangsúlyozni, hogy nem csak azoknak tud segíteni a mentor, akik egyáltalán nem rendel-keznek továbbtanulási céllal, hanem azoknak is, akik rendelkeznek ugyan, de pályaválasztási dilemmában szenvednek.

Globálisan és hazánkban sem „...magánügy az iskolába járás" (ismeretlen szerző: iskolablog). Az oktatási intézmények hatékony mûködése fontos társadalmi érdekeket szolgál. $\mathrm{Az}$ iskolázottság ugyanis a társadalmi mobilitás egyik lehetséges útja, mely az egyén munkaerőpiaci esélyeivel is korrelál. Ezért különösen fontos a diákok iskolán belüli képzettséghez való juttatása, s a középfokú oktatásba való beintegrálása a diákoknak. Ezt a célt szolgálják a mentorprogramok is.

\section{A mentorprogram bemutatása}

A Tanítsunk Magyarországért Mentorprogram az egyetemista mentorok és általános iskolás diákok közötti kapcsolatteremtést segíti, továbbá kiemelkedő célja a mentorok részérôl az általános iskolák fiataljainak pályaorientációs támogatása. Különösen fontos a mentorok tevékenysége azért, mert az oktatási problémák fontos mérföldköve az általános iskolai döntésekben gyökeredzik. Az általános iskolás diákok középiskolai lemorzsolódásának egyik oka a nem megfelelő továbbtanulási döntések meghozatalában rejlik. Hazánkban a mai napig az egyik fő kihívást jelenti az alapfokúból a középfokú oktatásba való átmenet (Európai Unió Alapjogi Ügynöksége, 2014).

A Tanítsunk Magyarországért (TM) egy országos szintû egyetemi mentorprogram, melynek fô fókusza a hátrányos helyzetű térségek (A területfejlesztésről és a területrendezésről szóló 1996. évi XXI. törvény és a kedvezményezett járások besorolásáról szóló 290/2014. (XI. 26.) Korm. rendelet szerinti kedvezményezett járások) általános iskolás fiataljaira esik, ugyanakkor nem csak és kizárólag nehéz sorsú gyermekek képezik a célcsoportját. Összesen 9 egyetem bevonása történt meg jelen tanulmány kéziratának leadásáig (Debreceni Egyetem, Miskolci Egyetemen, Nyíregyházi Egyetem, Pécsi Tudományegyetem, Eötvös Loránd Tudományegyetem, Eszterházy Károly Egyetem, Kecskeméti Neumann 
János Egyetem, Szegedi Tudományegyetem, és a Magyar Agrár- és Élettudományi Egyetem) és immáron 70 általános iskola csatlakozott hozzá. A programba való bevont iskolák és egyetemek számanak növekedése a program ígéretességének előrejelző mutatója. Tervben van többek között, hogy Gyöngyösön, Gödölloón, Keszthelyen és Kaposváron is elindítják a programot (tanitsunk.hu), melynek köszönhetően már országos lefedettségú jó gyakorlattá terebélyesedne a Tanítsunk Magyarországért mentorprogram.

Jelen mentorprogram különlegessége, hogy a mentor-mentorált közötti életkori távolság nem annyira hangsúlyos. A Tanítsunk Magyarországért Mentorprogram az egyetemistákat és az általános iskolás diákokat kapcsolja össze egy közös tevékenység keretén belül. A két célcsoport egyazon sajátossága, hogy az oktatásban vesznek részt, csak annak más-más intézménytípusában, más-más színterén. A mentor tapasztalata azon alapszik, hogy ő maga megjárta már azokat az oktatási lépcsőfokokat, mellyel mentoráltja jelenleg szembesül, így jobban tud azonosulni azzal az élethelyzettel, mely egy általános iskolás diákot jellemez, s hatékonyan képes segíteni is ezáltal. Ố maga saját életútjából származó tapasztalatait konzekvens módon képes beépíteni a mentorálás folyamatába (Ceglédi és tsi., 2020). A megfelelő mentori tevékenység tervezéséhez ugyanis elengedhetetlen a tanulói összetétel jellemzőinek, sajátosságainak alapvető ismerete, melyben élen járnak azok a mentorok, akik egy generáció szülöttjei/gyermekei (z generáció- 19952009). A mentorálás sikerét a generációs azonosság felerősítheti (a generációs különbségek eltávolíthatnak). Természetesen ezt a tendenciát bizonyos esetek/helyzetek felülírhatják, nem kell kizárólagos evidenciának tekinteni, mégis jelen program esetében érdemes kitérni rá.

A Tanítsunk Magyarországért Mentorprogram egy központi kezdeményezés hatására létrehozott és támogatott program, mely elsődlegesen, de nem csak és kizárólag a mentorált fejlődése céljából jött létre. A kétirányú, kölcsönös fejlődést hangsúlyozza a reciprok mentorálás fogalma (Bencsik és Juhász, 2017). A program érdekessége, hogy a társadalom eltérô, különbözô tagjait kapcsolja össze, akik más körülmények között kevésbé valószínú, hogy érintkeznének egymással. Anderson az iskolákat ,intellektuális ügynökségnek" nevezi (idézi Ceglédi, 2018, 10 o.), ahol az alsóbb rétegekből származók a felsőbb rétegeknek az etikettjével, szokásaival, és nyelvjárásával érintkezhetnek. A mentorprogram ilyen formán a társadalom eltéró tagjainak is a gyújtóhelye. A mentorálás során olyan kapcsolatban vehetnek részt, melyben „feloldódnak a társadalmi korlátok" (Pusztai, 2004; idézi Ceglédi és tsi, 2018, 53 о.).

A mentor továbbá értelmezhető egyfajta szociális katalizátorként is, mert kapcsolatrendszerének köszönhetően becsatornázhatja a mentoráltat a társadalmi integrációs folyamatokba. A mentor ilyen formán hidat képez az egyén és a társadalom között, s az egyént a lehetőségekhez való hozzáférésben segíti; áthidalja az információs szakadékokat, továbbá abban támogatja, hogy képes legyen az ôt körülvevő környezeti feltételek kiaknázására, katalizálására. Emellett az egyén belső erőforrásaira is felhívja a figyelmet, s az abban rejló potenciálra (Ceglédi és tsi, 2020). Mindezek növekedésével arányosan a mentoráltak esetében az életcélok horizontja kitágulhat.

\section{Módszer}

Kvantitatív kutatásunkat 2019-ben végeztük a Tanítsunk Magyarországért Mentorprogram mentorjelöltjei körében. A program az ország négy egyetemén (Debrecen, Nyíregyháza, Pécs, Miskolc) indult el összesen 500 fővel. Kutatásunkban a populációból kifejezetten a DE hallgatóira fókuszáltunk ( $\mathrm{n}=151$ fö). A hallgatók függetlenül kortól, nemtől, munkarendtől és szaktól jelentkezhettek a mentoráláshoz kapcsolódó elméleti kurzusra (egy féléves TM1 kurzus), amelyért kreditet is kaptak. A mentorjelöltek a kurzus sikeres teljesitését 
követően dönthettek arról, hogy megkezdik-e a mentorálást, amelyért ösztöndíj is jár. Közülük 72 fô îrta alá végül a mentori szerződést és vett részt a mentoráláshoz kapcsolódó nyári táborban, valamint a mentorálást megelőző interjún.

Az itt elemzett bemeneti mérést a TM1 kurzus elején végezték a mentorjelöltek körében. Kutatásunkhoz a Ceglédi, Engler, Hüse, Berényi és Szűcs (2019) által összeállított és lekérdezett kérdőívet használtuk fel. A kérdőívben vizsgált föbb dimenziók a következők voltak: demográfiai adatok (családi háttér, diákok és szülők iskolai végzettsége, tanulmányok), motivációk (amiért a mentorprogramba jelentkeztek), félelmek, aggályok, személyes tapasztalatok a mentorálásban stb. A kérdőív többszerzős voltánál fogva változatos összetételú; tartalmazott nevelésszociológiai, pszichológiai jellegú teszteket is (redukált életesemény skála, reziliencia kérdőív, változási készenlét teszt). Kutatásunkban a hallgatók rekrutációs bázisát vizsgáló és a motivációjukat feltáró kérdésekkel foglalkoztunk. Tanulmányunkban azt tekintjük mentorjelöltnek, aki nyitott a mentorálás tevékenysége iránt, érdeklődést mutat a professzionális mentorálást megalapozó elméleti és módszertani ismeretek iránt, ugyanakkor még nem mentor a programban, csak ún. potenciális mentor. Felhívnánk arra a figyelmet, hogy ez nem zárja ki annak a lehetôségét, hogy volt/vagy jelenleg is mentor egy másik programban.

\section{Kutatási kérdések, hipotézisek}

Jelen tanulmány keretein belül a mentorok demográfiai mutatóival kapcsolatban kíváncsiak vagyunk arra, hogy milyen településrôl érkeznek és milyen családi háttérrel rendelkeznek az egyetemista mentorok.

(1) Első hipotézisünk szerint a mentorálásra jelentkező hallgatók körében felülreprezentáltan vannak jelen a vidéki és falusi hallgatók. Hipotézisünket arra a feltételezésre alapozzuk, hogy a kistelepülésekról származó hallgatók saját tapasz- talataik alapján nagyobb tudással rendelkeznek arra vonatkozóan, hogy egy hátrányos helyzetú településen mekkora hozzáadott értéke lehet egy mentorprogram múködésének.

A hallgatók képzési területi eloszlásával kapcsolatban a következő hipotéziseket fogalmaztuk meg:

(2) Úgy véljük, hogy fooként bölcsészhallgatók jellemzik a mentorjelöltek összetételét. Egyrészt azért gondoljuk, mert a mentori tevékenység a tanári szakma mellett a segítő szakmával mutat még rokoni kapcsolatot (Godó, 2021b), melyek mind a bölcsészettudományhoz állnak közel.

(3) Azt is feltételezzük, hogy inkább segítő szakmákból érkeznek a mentorok, ugyanis ők maguk szakmai fejlődést várnak a mentorálás során. Esetükben feltehetően szakválasztásukat is a segíteni akarás jellemezte, így nagyobb a nyitottságuk a hasonló programok iránt. Továbbá a segító szakmából érkező motivációját köztudattan inkább jellemzi a segíteni akarás, mint a más pályára készülőkét.

A motivációkkal kapcsolatban a következő feltételezéseket fogalmaztuk meg:

(4) A mentorjelöltek motivációival kapcsolatban azt feltételezzük, hogy a férfiak és nők tekintetében különbségeket tapasztalhatunk. Feltételezésünket a nemi sztereotípiákra alapozzuk (Diekman és Eagly, 2000), s úgy véljük, hogy a férfiak esetében a kihívás erőteljesebb motivációs tényező lehet.

(5) A hátrányos helyzetű - megjegyzés: a „hátrányos helyzetú hallgató" kategóriáját mások olyan módon operacionalizálják, hogy az ide tartozó hallgató legalább két szempontból nehézségekkel néz szembe a következőkbőll: magas testvérszám, alacsony státusú településtípus, alacsony iskolázottságú, elhunyt vagy munkanélküli szülő (Ceglédi, 2009 izéi: Pusztai, 2011:144). Meghatározásunknál ezt vettük alapul - ld. később index mutató létrehozása - mentorjelölt hallgatók esetében az ösztöndíj domináns motiváló tényező a mentori tevékenység választásában, ugyanis anyagi helyzetük 
szempontjából minden juttatás nagy segítséget jelenthet számukra, így az ösztöndíj is.

(6) Utolsó hipotézisünkben azt feltételezzük, hogy gyakoribb lesz a hátrányos helyzetû mentorjelöltek esetében az a válasz, miszerint jobban ismerik leendő mentoráltjaik társadalmi helyzetét. Ezt az állitásunkat azokra a szakirodalmi eredményekre alapozzuk, melyek szerint a hátrányos helyzetú tanulók életében gyakrabban fordulnak elő negatív megterhelő életesemények (ld. HolmesRahe-skála kérdéseiből újraalkotott Redukált Életesemények Skála (RÉS) - a kérdőívben Hüse által beszúrt kérdésblokk. Ez is a kérdőívünk része volt, azonban egy másik tanulmány tárgyát képezi. Jelenleg pedig elérhető az alábbi szakdolgozatban: Godó K. (2021). A reziliencia háttértényezőinek vizsgálata a debreceni egyetemisták körében. (Szakdolgozat - mentálhigiéné szakirányú továbbképzés. Debrecen: Debreceni Egyetem). Pearce, Down és Moore (2008) arra jutottak, hogy gyakorta előfordul, hogy az alacsony társadalmi státuszú hallgatók miután diplomát szereztek, visszatérnek a származási közösségükbe annak érdekében, hogy megszerzett tudásukat a kisközösségüknek a javára fordítsák.

\section{Minta}

Feltáró jellegư kérdőíves kutatásunkban a kitöltők rekrutációs bázisát térképeztük fel (demográfiai és képzési rekrutáció). Teljeskörû lekérezést végeztünk, melyben a válaszadási hajlandóság $88 \%$ volt. A nem tekintetében az alábbi megoszlás jellemzi a mintánkat; a résztvevők 64,9\%-a nő, 35,1\%-a férfi (1.táblázat).

\section{1. tábláat: $A$ megkérdezettek neme ( $n=151)$}

\begin{tabular}{|l|c|c|}
\hline Neme & Fö & $\mathbf{\%}$ \\
\hline Férfi & 53 & 35,1 \\
\hline Nő & 98 & 64,9 \\
\hline Összesen & 151 & 100 \\
\hline
\end{tabular}

Ez az arány megfelel a régió felsőoktatásában tapasztalt átlagos nemi arányoknak (Fényes, 2009). A felsőoktatásbéli nőtöbblet lehetséges okaira jelen tanulmány keretein belül nem térnénk ki, ugyanakkor ebben a kérdéskörben figyelemreméltó az eltérő karok, szakok közötti szelekció.

A megkérdezettek átlagéletkora $M_{\mathrm{kor}}=22,54$ év volt $(\mathrm{SD}=4,56)$. A legfiatalabb résztvevő 18 éves, a legidősebb 45 éves volt (levelező hallgató).

\section{Eredmények}

Ezt követően a mentorjelöltek települési eloszlását vizsgáltuk meg, melyre első hipotézisünk is vonatkozott. A megkérdezettek 69,3\%-a származik városból, s 30,7\%-a falusi. A Mikrocenzus $(2016,18$.$) adataival tulajdonképpen egybecsenge-$ nek a kapott eredmények, miszerint a fóvárosban és a megyeszékhelyeken magasabb a diplomával rendelkezők aránya. Ilyen értelemben nem tapasztalunk különbséget a potenciális mentorjelöltek esetében, mert nem teljesült az a hipotézisünk, miszerint ők többségében faluból származnak. Ez köszönhetố az eleve kevesebb falusi egyetemisták arányának is a felsőoktatásban.

A szülők végzettségének tekintetében elmondható, hogy 46 fő $(31,3 \%)$ édesapja legfeljebb szakmunkás, míg 68,7\% (101 fö) édesapja legalább érettségivel rendelkezik. Az anya legmagasabb végzettsége tekintetében azt találtuk, hogy 28 fö $(18,8 \%)$ édesanyja legfeljebb szakmunkás, míg 121 fó $(81,2 \%)$ édesanyja legalább érettségit szerzett. Andor (2002) szerint azok, akiknek szülei diplomásak, ők jellemzően több időt töltenek el az iskolarendszerben, vagyis több évig tanulnak, szemben a nem diplomás szülők gyermekeivel. Eredményeink többségében azt mutatják, hogy a megkérdezett egyetemisták családi hátterét tekintve nem feltétlen csak középfokú vagy felsőfokú szülők jelennek meg, de mégis nagyobb a magasabban kvalifikált szülők aránya. 
Ezt követően a szülók iskolai végzettségének állandó lakhely településtípusával való összefüggését vizsgáltuk (lásd: 3. és 4. ábra). Jellemzően a falusi résztvevők esetében volt az édesapák között magas a szakmunkást végzők aránya (édesapa: $\chi^{2}(2)$ $=3,97, \mathrm{p}=0,137)$, míg az anyák legmagasabb végzettsége nem mutatott ilyen erős összefüggést a településtípussal (édesanya: $\chi^{2}(2)=2,5, \mathrm{p}=0,293$ ). Mégis ez a fajta adat is jól mutatja a felsőoktatásban jelen lévő hallgatók családi hátterének diverzifikált voltát, mely az oktatás expanziójának egyik hozadéka. Eredményeink alapján a városiaknál éló szülőknél magasabb a diplomások aránya, ami a magyar demográfiai trendekre rímelő adat.

\section{Karok szerinti megoszlás és segítő szakmát tanulók aránya}

Előzetes hipotézisünkben azt feltételeztük, hogy a mintában felülreprezentáltak a Bölcsészettudományi Kar hallgatói. A kérdőívünket kitöltők közötti sokrétűség az eltérő karok arányaiban is jól látszik (lásd: 5. ábra). Azt láthatjuk, hogy a Debreceni Egyetem majdnem minden karáról (14 karBölcsészettudományi Kar (BTK); Természettudományi és Technológiai Kar (TTK);

\section{3. ábra: $A z$ apa iskolai végzettsége (\%) $(n=151$ fö) $(p=0,137)$. Forrás: Szerző}

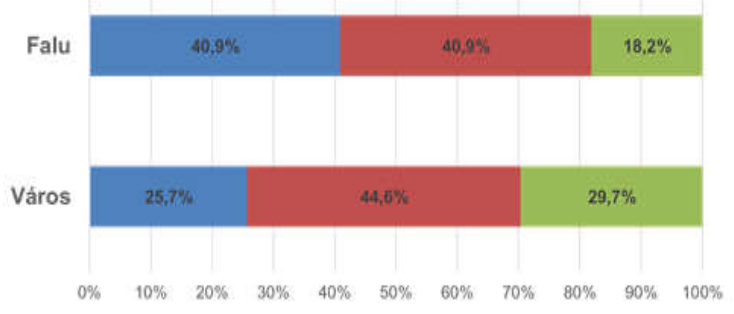

" legfeljebb szakmunkàs "èrettségi, vagy arra épūtố szakképzés, FSZ = diploma
Mezőgazdaság-, Élelmiszertudományi és Környezetgazdálkodási Kar (MÉK); Népegészségügyi Kar (NK); Gazdaságtudományi Kar (GTK); Mûszaki Kar (MK); Gyermeknevelési és Gyógypedagógiai Kar (GYGYK); Informatikai Kar (IK); Gépészmérnöki Kar (GK); Általános Orvostudományi Kar (ÁOK); Állam- és Jogtudományi Kar (ÁJK); Fogorvostudományi Kar (FOK); Gyógyszerésztudományi Kar (GYTK); Egészségügy Kar (EÜ) jelentkeztek hallgatók, leszámítva a Zenemúvészeti Kart (ZK), a Gyógyszerésztudományi Kart (GYTK), a Fogorvostudományi Kart (FTK) és az Egészségügyi Kart (EÜ).

A válaszok alapján hipotézisünk teljesült, hiszen a Bölcsészettudományi Kar hallgatói felülreprezentáltak a mintánkban (43,7\%), ugyanakkor figyelembe kell venni azt a tényt is, miszerint önmagában eleve több a hallgató a BTK-n, azaz egy nagy tömegeket mozgosító karról van szó, ahol arányait tekintve a hallgatói alapsokaság eleve magas a Debreceni Egyetem többi karához képes (lásd: 2. táblázat).

A Debreceni Egyetem hallgatói statisztikái (2021) szerint az ÁOK, BTK, GTK, illetve a TTK tartozik a „legnépesebb” karok közé (lásd: 2. táblázat).

\section{4. ábra: Az anja iskolai végzettsége telepiilés-tipusonként \\ (\%) $(n=151$ fö) $(p=0,293)$. Forrás: Szerzö.}

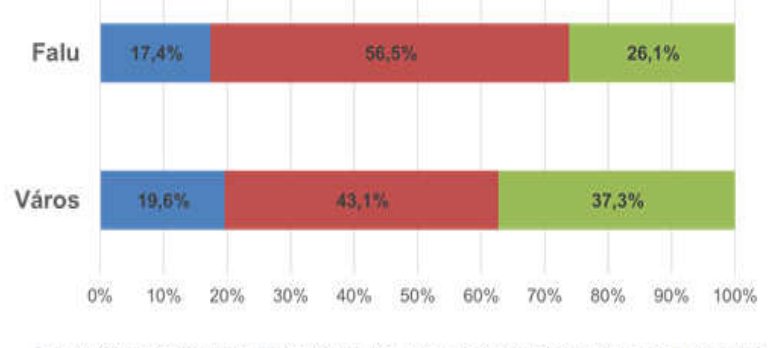

- legfeljebb szakmunkás = érettségi, vagy arra épülö szakkèpzés, FSZ = diploma 
5. ábra: Karok, ahonnan a mentorjelöltek jelentkętek (\%) (n=151, forrás: saját adatbázis)

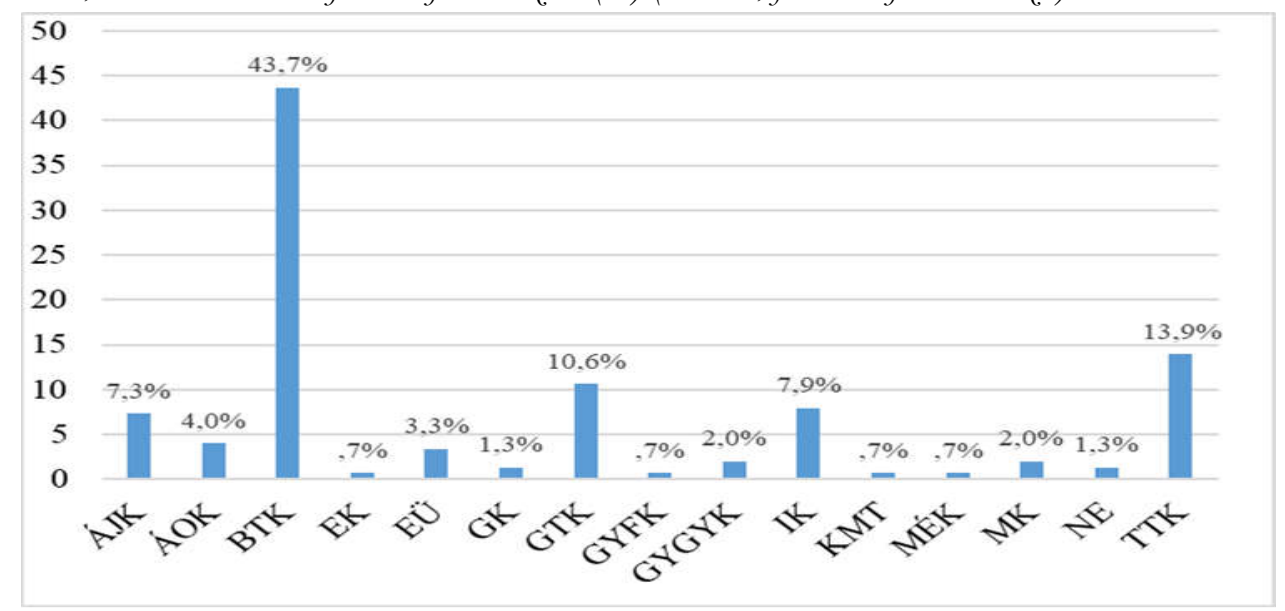

2. táblázat: A Debreceni Egyetem hallgatóinak 2021. márc. 15-i létszámadatai finanszírozási forma szerint (forrás: Debreceni Egyetem, hallgatói statisz̨tikái, letöltés ideje: 2021. 05. 14.)

\begin{tabular}{|c|c|c|c|c|c|c|c|c|c|c|c|c|c|}
\hline \multirow{2}{*}{ Kar } & \multicolumn{6}{|c|}{ Nappali tagozat } & \multicolumn{6}{|c|}{ Levelezö, távoktatási tagozat } & \multirow{2}{*}{ Összesen } \\
\hline & $\begin{array}{c}\begin{array}{c}\text { Allami } \\
\text { támogatott }\end{array} \\
\end{array}$ & $\begin{array}{c}\text { Állami } \\
\text { osztöndijas }\end{array}$ & $\begin{array}{l}\text { Költség- } \\
\text { téritéses }\end{array}$ & $\begin{array}{l}\text { Önkölt- } \\
\text { séges }\end{array}$ & Egyéb & összesen & $\begin{array}{c}\text { Állami } \\
\text { támogatott }\end{array}$ & \begin{tabular}{|c|} 
Állami \\
osztöndijas
\end{tabular} & $\begin{array}{l}\text { Költség- } \\
\text { téritéses }\end{array}$ & $\begin{array}{l}\text { Önkölt- } \\
\text { séges }\end{array}$ & Egyéb & Összesen & \\
\hline ÁJK & & 315 & 14 & 544 & 1 & 874 & & 108 & 32 & 490 & 2 & 632 & 1506 \\
\hline ÁoK & 1 & 1333 & 48 & 1755 & 213 & 3350 & & 6 & 1 & 8 & & 15 & 3365 \\
\hline BTK & & 2042 & 4 & 233 & 18 & 2297 & & 35 & 2 & 456 & & 493 & 2790 \\
\hline EK & & 491 & 3 & 78 & & 572 & & 456 & 2 & 99 & & 557 & 1129 \\
\hline FOK & 1 & 246 & 7 & 370 & & 624 & & & & & & & 624 \\
\hline GTK & & 1957 & 1 & 1028 & 10 & 2996 & & 710 & 11 & 613 & & 1334 & 4330 \\
\hline GYGYK & & 582 & & 21 & 4 & 607 & & 661 & 2 & 377 & & 1040 & 1647 \\
\hline GYTK & & 301 & 2 & 197 & 5 & 505 & & & & & & 0 & 505 \\
\hline IK & & 1136 & 7 & 510 & 1 & 1654 & & 15 & 15 & 173 & & 203 & 1857 \\
\hline MÉKK & & 785 & 11 & 207 & 3 & 1006 & & 192 & 6 & 153 & & 351 & 1357 \\
\hline MK & 1 & 1094 & 60 & 970 & 5 & 2130 & 1 & 270 & 62 & 408 & & 741 & 2871 \\
\hline NK & & 707 & & 249 & & 956 & & 146 & & 76 & & 222 & 1178 \\
\hline TTK & & 1355 & & 586 & 183 & 2124 & & 24 & 1 & 181 & & 206 & 2330 \\
\hline$z K$ & & 189 & & 6 & & 195 & & 12 & & & & 12 & 207 \\
\hline PhD képzés & & 684 & & 311 & 2 & 997 & & & & 189 & & 189 & 1186 \\
\hline Összesen & 3 & 13217 & 157 & 7065 & 445 & 20887 & 1 & 2635 & 134 & 3223 & 2 & 5995 & 26882 \\
\hline
\end{tabular}

Harmadik hipotézisünkben feltételeztük, hogy a mentori tevékenység, illetve a pedagógusok és segítő szakmát végzők feladatkörei közti átfedések következtében a segítő szakmára készülő hallgatók felülreprezentáltak a mentorjelöltek között. Így megvizsgáltuk, hogy felülreprezentáltak-e a segítő szakmát tanulók a mintában. A résztvevők közül 151 főből 31,3\% segítő szakmára készül (pszichológus, szociális munkás stb.). Feltételezhetjük, hogy ezek a hallgatók tudatosan készülnek későbbi választott pályájukra, és a pályaszocializációt erősítendő végeznek mentori tevékenységet tanulmányaik alatt. Fontos azonban, hogy nem csupán azok számára jelenthet a mentorálás többletértéket, akiknek a szakjához közelebb áll a végzett tevékenység. Sőt nemcsak azok profitálnak 
a mentorálásból, akiket mentorálnak, hanem tulajdonképpen párhuzamosan fejlődésről beszélhetünk, amely a mentor számára is kedvező (ld. reciprok mentorálás).

\section{Motivációs vizsgálat}

A mentorjelölt hallgatókat arról kérdeztük, hogy miért jelentkeztek mentornak. Nyolc válaszlehetőség közül maximum hármat jelölhettek meg a hallgatók. Választotta - nem választotta kódolással elemeztünk. Az adott válaszlehetőséget megjelölók százalékos arányait nemenként lebontva a 6. ábra mutatja.

Az egyes válaszlehetőségek jelölése és a nem közötti összefüggések feltárására Khi-négyzet próbát is végeztünk, ezek eredményeit a 3. táblázat tartalmazza. Amint látható, a segíteni akarás, a politikai indíttatás, illetve az ösztöndíj fontosságában találtunk szignifikáns eltérést, azonban az értelmes dolog és a hazát sújtó probléma megoldásának fontossága is tendenciaszintû eltérést mutatott nemenként, mindkét esetben a nők jelölték meg az adott opciót nagyobb arányban.

Mindenesetre láthatjuk, hogy a nők számára a három leggyakoribb tényező a következő: segíteni akarás, hazát sújtó probléma megoldása és a kihívás, míg a férfiak esetén a segíteni akarást az ösztöndíj követi a második helyen, továbbá a kihívás. A kihívás mindkét nem esetében a harmadik helyen szerepel, azonban a férfiak körében többen jelölték (52,8\%), viszont a kis értékkülönbség miatt hipotézisünkre (H4) vonatkozóan nem tudunk egyértelmú kijelentéseket tenni, miszerint az igazolódott volna.

6. ábra: $A$ „Miért jelentkeqtél mentornak?” kérdésre adott válaszok nemenként (\%) (n=151)

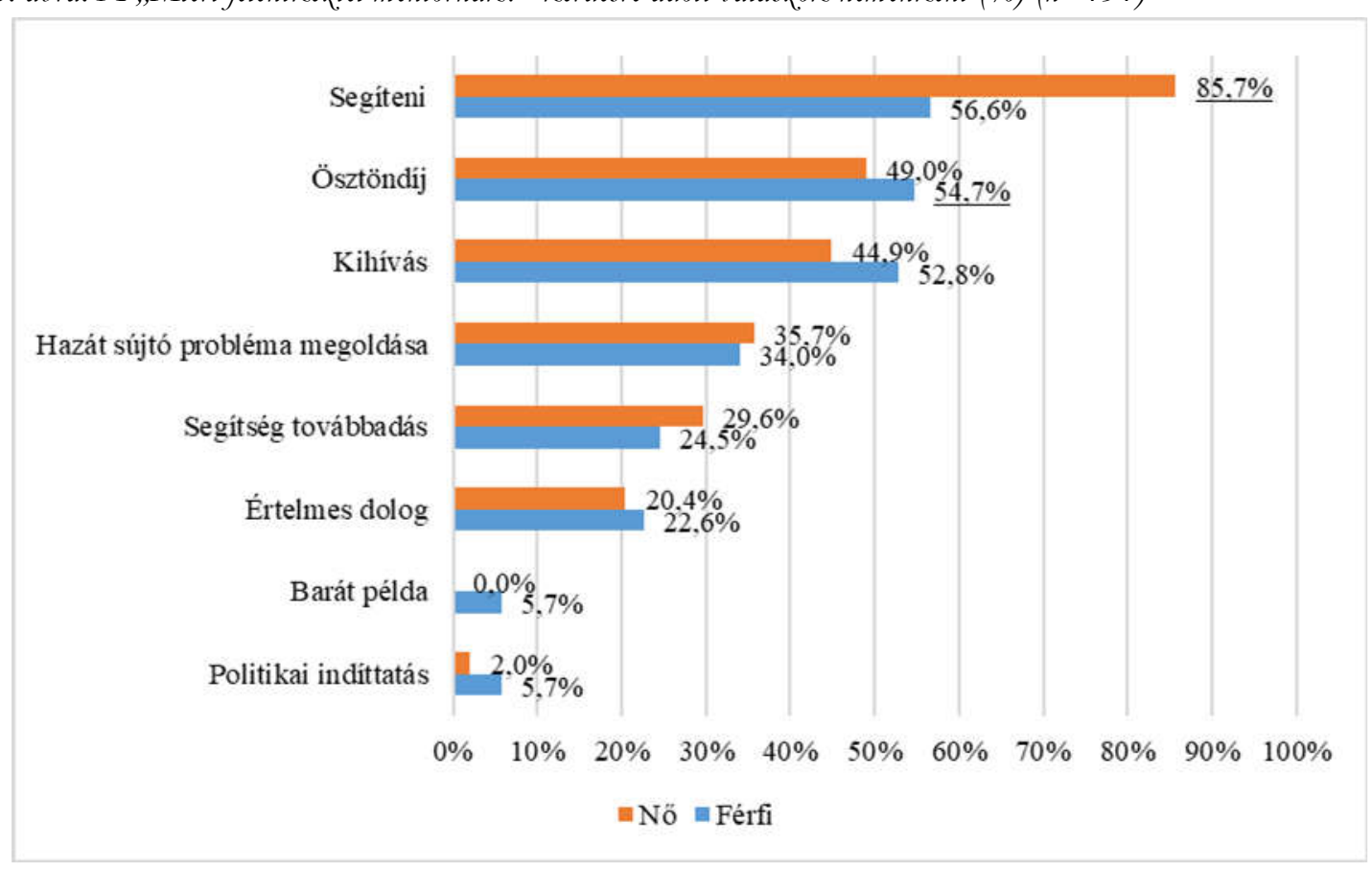

Megjegyzés: Az adjusztált squtenderd reziduálisok alapján felülreprezentált értékeket aláhúrással jelöltük 
3. táblázat: Az egyes válaszlehetöségek és nemek közötti összefüggések kbi-négyzet próbája

\begin{tabular}{l|c|c}
\hline $\begin{array}{l}\text { „Miért } \begin{array}{c}\text { jelentkeztél } \\
\text { mentornak?” } \\
\text { egyes itemei }\end{array} \\
\text { kérdés }\end{array}$ & $\chi^{2}$ & $\mathrm{p}$ \\
\hline Segíteni akarás & 15,76 & $<0,001^{* * *}$ \\
Kihívás & 0,87 & 0,35 \\
Értelmes dolog & 2,74 & 0,1 \\
Barát példa & 1,41 & 0,24 \\
Hazát sújtó probléma & 3,15 & 0,08 \\
Segítség továbbadása & 0,34 & 0,56 \\
Politikai indíttatás & 5,66 & $0,02^{*}$ \\
Ösztöndíj & 9,18 & $0,002^{* *}$ \\
\hline Jelmagyarázat: ${ }^{*} p<0,05 ;{ }^{* *} p<0,01 ; * * * p<0,001$
\end{tabular}

\section{Segíteni akarás}

A 6. ábra alapján a nők között nagyobb azoknak az aránya, akik a segítségnyújtást jelölték meg motívumként $(85,7 \%)$, a férfiak esetében közel 30\%kal kevesebben jelölték meg a segíteni akarást mint motivációs tényezőt $(56,6 \%)$. A segíteni akarás áll az első helyen mindkét nem esetében, ami egy erős belső motiváció biztos alapja. Ehhez kapcsolódik az a szemlélet is, miszerint a mentorálás az önkéntes munka egy formájaként is felfogható (Markos, 2019) attól függően, hogy az egyén a társadalmi problémák megoldására irányuló cselekvésként értelmezi-e a mentorálási tevékenységét. Továbbá fontos lehet, hogy általában a másoknak segíteni akarók esetében (ugyanígy a segíteni akaró mentoroknak) a másokhoz való affiliációs (kapcsolódási) motivációjuk/igényük igen nagy, s esetükben a környezeti, társadalmi problémákra érzékeny szemlélet jelenik meg.A kitöltő nôkre jellemző motivációk még a hazát sújtó probléma megoldása (35,7\%), ami szoros összefüggésben lehet azzal, hogy ők a mentorálással járó kihívásokat egyben egy társadalmi jelenségre való reflektáló, cselekvô módként értelmezik.

\section{Kihívás}

Eredményeink alapján mind a férfiak $(52,8 \%)$ mind a nők $(44,9 \%)$ közül sokan kihívást látnak a mentorálásban. Ennek oka lehet, hogy a mentorlással legtöbben egy korábban nem megszokott, új tevékenységben vesznek részt, ezáltal a hallgatók kilépnek saját komfortzónájukból. Ilyen formán ők kockázatot vállalnak, hiszen a siker ígérete habár ott lóg a levegóben, de nincs 100\%-os garancia rá. Ezek a hallgatók éppen egy újfajta kihívással szembenézve növelik saját kompetenciáikat végül (ld. kompetenciamotiváció). A mentorok jellemzőjében jelen van tehát a kockázatvállaló jelzó is (Gyarmathy, 2019), hiszen a szokatlan, idegen utak gyakori ismertetőjegye az is, hogy kockázatosak. Sokan természetesen szívesen haladnak inkább a megszokott úton, mert az „kockázatmentes övezet” (Gyarmathy, 2019: 62). A kihívásfókuszúak viszont gyakran felvállalják az új utakat, gyakran választanak látszólag ,periférikus utakat” (megjegyzés: ez nem egyenértékú a kerülő úttal ebben a megfogalmazásban), mint ahogy a reziliensek (megjegyzés: alapvetően pszichológiai fogalom; jelentése: „rugalmas ellenállóképesség”; a nehézségekkel szembeni rugalmas ellenállás, vagyis „boldogulás a nehézségek ellenére" (Ceglédi és mtsi. 2019). Masten (1990) szerint ez a fajta pszichés rugalmasság lehetővé teszi a sikeres alkalmazkodást a kihívást jelentő vagy fenyegető körülmények esetén.) is (Ceglédi, 2002). Ehhez az új úton való haladáshoz pedig motiváció kell. Nincs negatív motiváció, csak 
pozitív, sokkal inkább az a fontos, hogy mire irányul. A mentorálás feltételezi azt is egyúttal, hogy az egyén képesnek érzi magát arra, hogy mentorrá váljon, tehát van benne egy előzetes belső tudás/bizonyosság erről, amit később az elméleti kurzus megerősíthet vagy cáfolhat. Utóbbi ritkán fordul elő, kivéve akkor, ha hallgatók nem képesek reálisan felmérni az optimális kihívások mértékét/szintjét. A kockázatkerülők emellett nehezebben viselik el a bizonytalanságot, ami egy új kihívás esetén gyakori - pláne egy kísérleti jellegú mentorprogram esetén.

Ez külön fontos azért is, mert a megkérdezettek 13,3\%-a nem tudja, hogy mi a mentor feladata. Továbbá 23,3\% nem ismeri a mentorált réteget, tehát nem volt kapcsolata vele. Sokan pedig mivel nem tudják, hogy mi a mentorálás, nem is látják át annak folyamat-jellegét (26\%) (7. ábra).

\section{Értelmes elfoglaltság}

Diákok lévén mind a mentor, mind a mentorált rendelkezik szabadidővel, melynek felhasználásáról szabadon dönthetnek, s korántsem mindegy, hogy mire fordítják azt. A válaszadók közül többen jelölték az értelmes elfoglaltságot a mentorprogramba való jelentkezés egyik motivációjának. A megkérdezettek 31,1\%-a jelölte a 3 lehetőség egyikének ezt az opciót, 22,5\% férfiak körében és $32,6 \%$ a nők körében. A mentorprogramok lehető- séget adnak arra ugyanis, hogy az egyetemisták tartalmasan töltsék el a hallgatóéveket, s ne csak „,a felsőoktatás manifeszt elvárásaiba szúkült hallgatói életet" éljenek (Ceglédi és tsi, 2018, 53. o.). S mivel az alsóosztályok ifjúságára nem jellemző a magas szubkultúra fogyasztása (Kohlen, 1975) (megjegyzés: a szubkultúra fogalmát a szociológiába Albert Cohen vezette be.

A szubkultúra „azokat a jellegzetességeket fejezik ki, melyek a viselkedési formákat, öltözködést, ízlést, szórakozást, szabad-idei tevékenységet, zenét, sportot meghatározzák, mikor is figyelembe vesszük a kort, nemet, hivatás-beli- és szabadidőtöltési különbségeket. Így beszél-hetünk városiés falusi kultúráról; fiatalok és idő-sek, munkások és értelmiségiek kultúrájáról.”), így a szabadidővel ők sokkal inkább nem tudnak mit kezdeni, mint a felsőbb osztályok tagjai. Viszont ebbe az időintervallumba tudnak jól becsatlakozni a mentorprogramok is, amik tartalommal töltik meg ezt az időkeretet társadalmi osztályhovatartozástól független is, s így nemcsak a mentoráltnak, de a mentornak is a szabadidőeltöltés egy hasznos módját jelenti.

\section{Szakmai fejlődés}

Megvizsgáltuk továbbá, hogy szakmai fejlődés mennyire fontos a segítő és nem segítő szakmát tanulók körében (8. ábra).

7. ábra: A mentoráláshoz kapcsolódó félelmek (n=151) (\%, forrás: saját adatbázis)

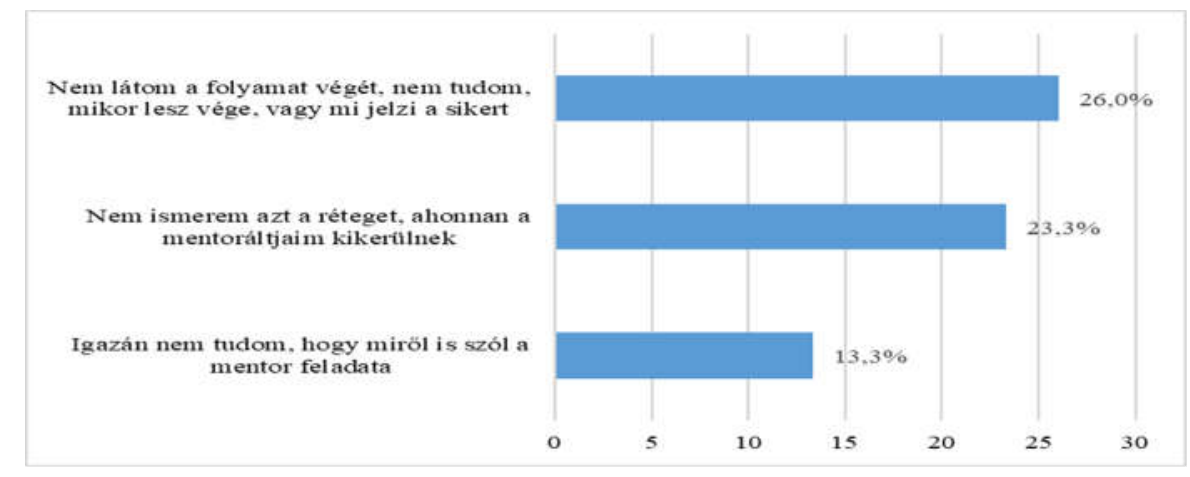


8. ábra: Szakmai fejlōdés fontossága segitó és nem segitő szakmában (\%, forrás: saját adatbázis)

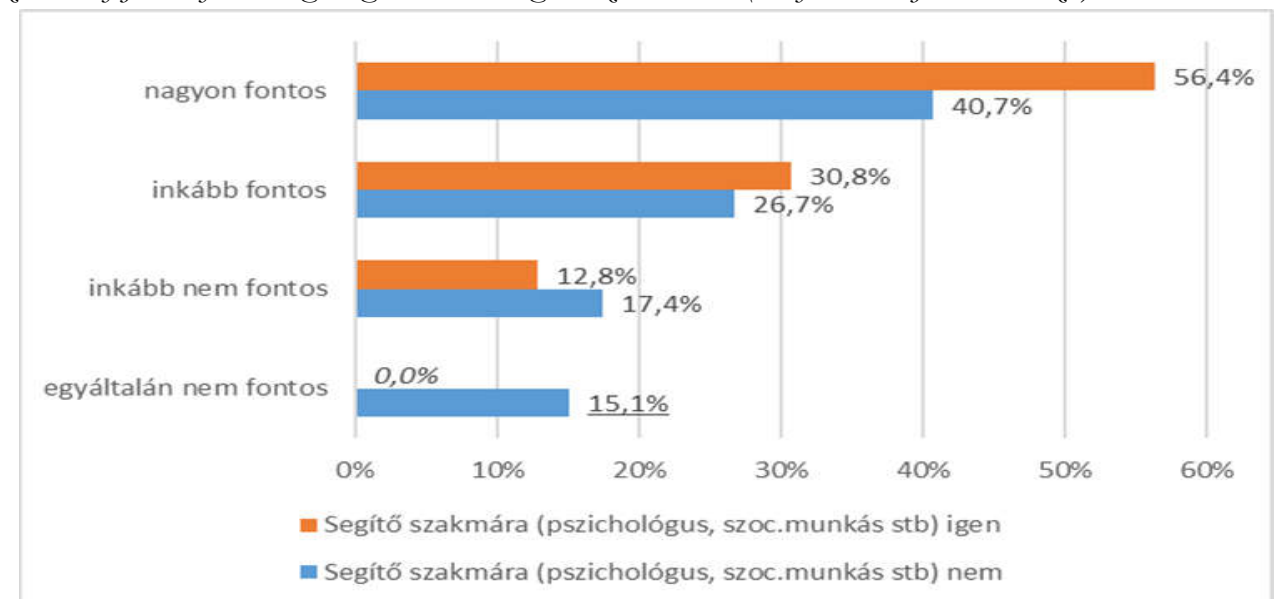

Megjegyzés: Az adjusztált sztenderd reziduálisok alapján felülreprezentált értékeket aláhúzással jelöltük, az alulreprezentált értéket pedig dőlttel.

Szignifikáns összefüggést találtunk a két változó között $\left(\chi^{2}(3)=7,86, p=0,05\right.$. A segítő szakmát tanulók jellemzően felülreprezentáltak azok között, akiknek a szakmai fejlődés inkább fontos $(30,8 \%)$ vagy nagyon fontos $(56,4 \%)$. Továbbá alulreprezentáltak azok között, akiknek inkább nem fontos $(12,8 \%)$ vagy egyáltalán nem fontos $(0 \%)$.

\section{Hátránnyal rendelkezők index változója}

Tanulmányunkban egy index változót hoztunk létre az alábbi változók bevonásával: településtípus, édesanya iskolai végzettsége, édesapa iskolai végzettsége és a családszerkezet. Az index létrehozásához dummy változókat képeztünk, ahol minden esetben az egyes jelölte a hátrány meglétét. Azokat, akik falun, kisebb községben élnek, egyessel jelöltük (hátránnyal rendelkezőnek számítva) szemben a városiakkal (akiket nullával jelöltünk). Ugyanígy jártunk el a szülók iskolai végzettségét tekintve is (az érettségivel nem rendelkező anya és apa esetén a hallgató egyes értékkel, legalább érettségivel rendelkező szülők esetén nullás értékkel volt jelölve). Továbbá figyelembe vettük a hátrányos helyzet megállapításánál, hogy valamilyen családszerkezeti deficit jellemző-e az adott családban (pl.: legalább 6 hónapig előfordulte vele, hogy egyszülős családban élt vagy nevelószülők nevelték az adott hallgatót stb.). Azokat, akiknél a családszerkezet érintett volt valamilyen módon, szintén egyessel jelöltük.

Ezt követôen összeadtuk az egyes változók értékeit, így kapva meg a hátrányos helyzetre utaló mutatót, ami alapján 3 kategóriát állítottunk fel: hátránynélküliek; 1 hátránnyal rendelkezők; 2 vagy több hátránnyal rendelkezők. Az egyes kategóriába tartozó eloszlást a 3 . táblázat mutatja:

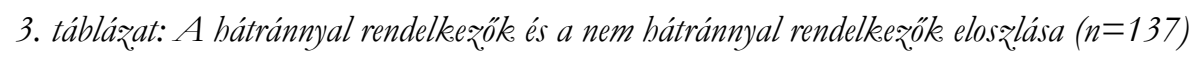

\begin{tabular}{|l|c|c|}
\hline & $\mathbf{N}$ & $\mathbf{\%}$ \\
\hline Hátrány nélküli & 37 & 27 \\
\hline 1 hátránnyal rendelkező & 57 & 41,6 \\
\hline Legalább 2 vagy több hátránnyal rendelkező & 43 & 31,4 \\
\hline Összesen & 137 & 100 \\
\hline
\end{tabular}


A motiváció és a hátrányos helyzet összefüggéseit Khi-négyzet statisztikával vizsgáltuk. Szignifikáns összefüggést csak egy esetben tapasztaltunk; a mentor ösztöndíj és a háttérváltozó vizsgálatának során $\left(\chi^{2}(2)=6,79, p=0,03\right)$. Eredményeink alapján meglepó módon a hátránynélküliek között nagyobb arányban vannak jelen azok, akik között a mentori tevékenységben az ösztöndíj fontos motiváció (54,10\%) (9. ábra), míg a legalább 2 hátránnyal rendelkezők között alulreprezentáltak azok, akik jelölték ezt a szempontot. Nem meglepó módon eredményeink azt rajzolták ki, hogy az egy, illetve kettő vagy több hátránnyal rendelkezők úgy vélik, hogy jobban ismerik a mentorált célcsoportot (10 ábra, $\chi^{2}(2)=$ $9,15, \mathrm{p}=0,010)$. Mivel többségében hátrányos helyzetú diákok vesznek részt a programban, ezért a több hátránnyal rendelkezők között többen érezhették úgy, hogy saját élethelyzetükből kifolyólag tisztában vannak a célcsoport körülményeivel.

Mindenesetre nem csak és kizárólagos a hátrányos helyzetűek aránya a mentoráltak között, ugyanis jellemzóen egy adott köznevelési intézményen belül osztályokat (7-8.) vonnak be, nem személyeket külön-külön egy-egy osztályból.

9 ábra: A mentori ösztöndíj motivációja és a báttérváltozó összefuiggése (oszlopszázaléke) (n=137) ( $p=0,034$, forrás: saját adatbáziss)

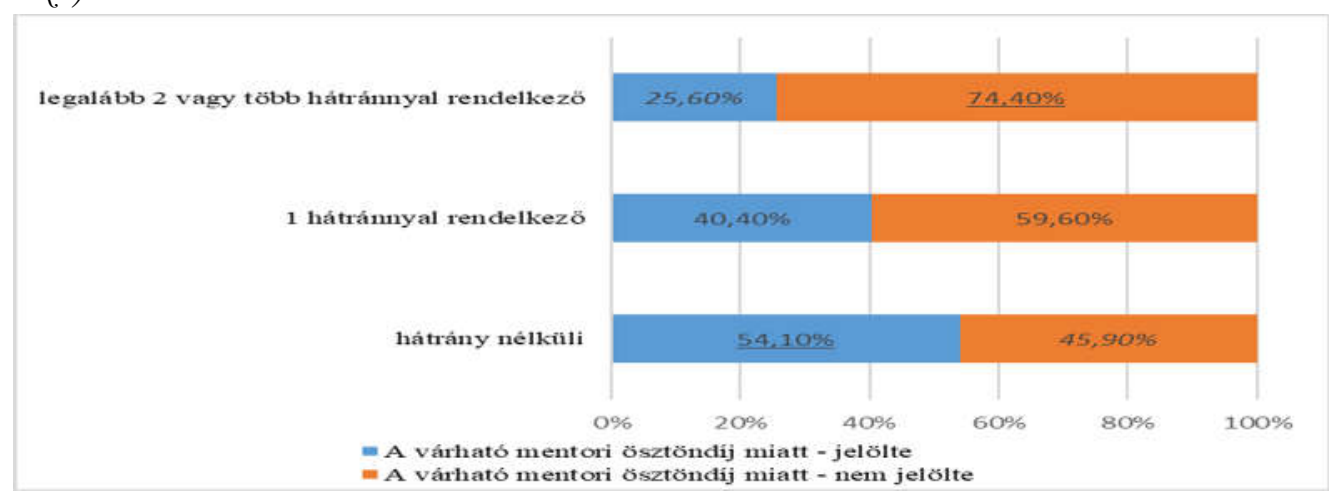

Megjegyzés: Az aláhúzott értékek esetében az adjusted standardized residuals értéke nagyobb, mint kettő, a dőlt értékek esetén pedig kisebb, mint kettő

10. ábra: A mentorált réteg ismerete a bátránnyal rendelkezớle és a nem bátránnyal rendelkezóók körében $(N=137)$ ( $p=0,010$, forrás: saját adatbázis)

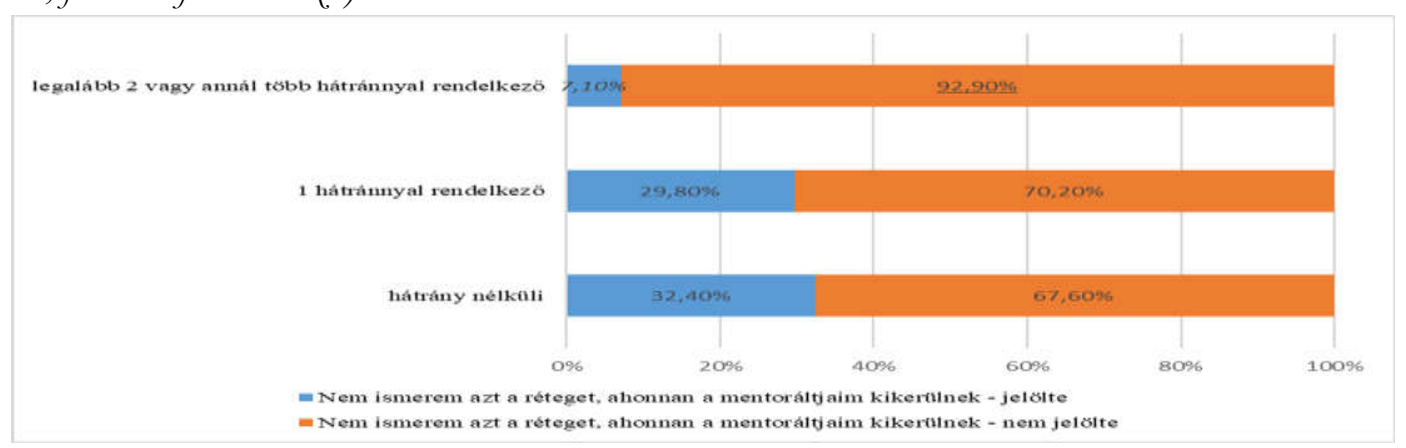

Megjegyzés: Az aláhúzott értékek esetében az adjusted residuals értéke nagyobb, mint kettő, a dőlt értékek esetén pedig kisebb, mint kettő. 


\section{Összegzés}

Kutatásunk összegzésében megvizsgáljuk a hipotéziseinkre kapott eredményeket.

(1) Első hipotézisünk, miszerint a mentorjelöltek inkább kistelepülésről, faluról származnak, nem igazolódott. A mintában a városi hallgatók voltak felülreprezentáltan jelen (69,3\%). Ez az eredmény egybecseng Balázs és Imre (2009) megállapításával is, miszerint a falusi fiatalok létszámarányait tekintve kisebb mértékben vesznek részt a felsőoktatásban, mint a városban élők.

(2) Második hipotézisünk arra vonatkozott, hogy a mentorjelöltek főként a Bölcsészettudományi Kar hallgatói. Ez igazolódott volna, de a hipotézis újra gondolásra érdemes, ugyanis ezen eredményünk nyilván összefüggésben állhat azzal is, hogy a Debreceni Egyetem egyik legnagyobb kara a bölcsész.

(3) Továbbá a harmadik hipotézisünk csak részben nyert megerôsítést, mely arról szólt, hogy a segítő szakmát tanulók nagymértékben jelen vannak a mentorjelöltek hallgatói összetételében. A megkérdezettek 31\%-a segítőszakmára készül (pszichológus, szociális munkás stb.). Molnár (2014) a felvi.hu statisztikáinak vizsgálata alapján arra a következtetésre jutott, hogy a segítő szakok (szociális munka, szociálpedagógia, andragógia, szociálpolitika) iránti érdeklődés 2006 óta csökken. Emellett jelentős volt a pedagógusok aránya is, azonban ők már nem feltétlen a bölcsész (megjegyzés: a kétszakos tanárképzésben az eltérō karhoz tartozó szakok esetén a hallgató ABC sorrend szerint előbb lévô szakja alapján határozzák meg, hogy adott esetben TTK vagy BTK-s hallgatónak számít-e elsődlegesen - ez természetesen más szakokkal is behelyettesíthetô) kategóriái alá tartoznak.

(4) A motivációval kapcsolatos hipotéziseink közül a negyedik tekintetében nem bizonyult markáns különbség a két célcsoport között. Az egyetemista mentorjelöltek esetén fontos belső indíttatású motivációs tényező a másokon való segítés, mint ahogy a kihívás is jelentős motivációs faktornak bizonyult.

(5) A hátrányos helyzetűek esetén viszont nem igaz, hogy a mentori ösztöndíj jelenti a mintákban szereplő mentorjelöltek fó motivációját. Ez a felismerésünk tanulmányunk egyik fő belátása. (6) Utolsó hipotézisünk is, miszerint az egy vagy több hátránnyal rendelkező hallgatók jobban ismerik a mentorált célcsoportot, igazolódott. A saját tapasztalatból származó tudás pedig alapja lehet a hatekony segítségnyújtásnak.

Összességében elmondható, hogy a mentorálás egy innovatív forma, mely „innovatív magatartást”, nyitott magatartást igényel a mentorok részérôl. A mentorálás elméleti és gyakorlati tudásbóvítést is magában foglal. Olyan praktikus tudást kaphatnak a mentorok, mely később az élet hétköznapi szituációiban, az iskolán túl is megtérülhet (Falus, 2003). A mentorálás empirikus hozzáférést biztosít a valóság egy bizonyos szegletéhez, miközben tágítja a hallgató horizontját és erôsíti a másokkal való kapcsolatát. Ez a fajta jó gyakorlat később megvédheti a pályakezdőket (főként a pedagógusokat) a „reality schock” (valóságsokk) „élményétől” (Szivák, 1999).

A szakemberek úgy vélik, hogy a motiváció kialakításában az intézménynek nagy szerepe van (Bárányné és tsi, 2020). A mentorkurzusra jelentkezők számából ítélve a Debreceni Egyetem ilyen téren jól teljesít. A Tanítsunk Magyarországért Mentorprogram elindulásának évében (2019) a Debreceni Egyetemről jelentkezett a legtöbb hallgató (151 fó az országos 500-ból). Úgy véljük, fontos a mentorálás általános iskolai színtéren való jelenléte, továbbá az egyetemek extrakurrikuláris kínálatának is egyik kuriózumát jelenti a mentorprogramban való részvétel. Jelen kutatásunk céljai között szerepel, hogy növelje a Tanítsunk Magyarországért Mentorprogram szakmai színvonalát, feltérképezze a mentorok rekrutációs bázisát és motivációik forrását. Eredményeink ezek által fontos 
visszajelzést jelenthetnek a program koordinátorai felé.

\section{Irodalom}

Andor (2002). Diplomás szülók gyermekei. Educatio, 2, 191-210.

Balázs É. \& Imre A. (2009). Felsőoktatás és élethosszig tartó tanulás. Az LLL a felsőoktatásban. In Felsőoktatás - Adatok és tendenciák. Budapest: OFI.

Bandura, A. (1997). Collective Efficacy. In Bandura, A. (Ed.). Self-efficacy: The exercise of control. New York: Freeman. 477-525.

Bandura, A. (1994). Self-efficacy. In V. S. Ramachaudran (Ed.). Encyclopedia of buman behavior (4), 71-81. New York: Academic Press.

Bander K., Galántai, J., Kállai G. \& Szabó Z. A. (2015). In Kállai (Ed.). Az ifjúsági mentorálás. (Youth mentoring). Budapest: OFI.

Bábosik Z. (2001). Értékközvetítés napjainkban. Új Pedagógiai Szemle, 51(12), 3-10.

Bárányné Dr. Jámbori Sz. Horvát-Militityi T. \& Ráczné Török E. (2020). Mentorbáló. Szeged: Szegedi Tudományegyetem.

Bencsik A. \& Juhász T. (2017). A mentori gyakorlat elmélete. In Vilmányi M. \& Kazár K. (Ed.). Menedzsment innovációk az ü̃leti és a nonbusiness szférákban. Szeged: SZTE. 379-390.

Bourdieu，P. (1999). Gazdasági tóke, kulturális tôke, társadalmi tőke. In Angelusz R. (Ed.). A társadalmi rétegzódés komponensei. Budapest: Új Mandátum.

Budapesti Intézet jelentése (2016). https://www. justiceinitiative.org/litigation/open-societyinstitute-budapest-v-hungary (Letöltés ideje: 2020. 10. 10.)

Ceglédi T. (2018). Ugródeszkeán Reziliencia és társadalmi egyenlótlenségek a felsöoktatásban. Debrecen: CHERD Kutatóközpont.

Ceglédi T., Godó K., Kiss A. \& Szathmáriné Csőke, K. (2019). Reziliencia a mentorálásban. In Varga, A., Andl, H. \& Molnár-Kovács Zs.
(Ed.) Neveléstudomány - Horizontok és dialógusok. Absztraktkötet. 285.

Ceglédi T., Hamvas L., Katona Cs., Kiss A., Torner B. \& Vas S. (2018). Ugródesžka lendülettel - Rezৃiliens Wális szakkeollégisták. Debrecen: Wáli István Református Cigány Szakkollégium.

Coleman, J. S. (1994). Társadalmi tőke. In Lengyel Gy. \& Szántó, Z. (Ed.). A gazdasági élet szociológiája. Budapest: Aula.

Dávid M., Estefánné Varga M., Farkas Zs., Hídvégi M. \& Lukács I. (2006). Hatékony tanulómegismerési technikák: Oktatási segédletek pedagógus továbbképrésben résżtvevök számára. Budapest: SuliNova Kht.

Diekman, A. B., \& Eagly, A. H. (2000). Stereotypes as dynamic constructs: Women and men of the past, present, and future. Personality and Social Psychology Bulletin, 26(10), 1171-1188. doi: $10.1177 / 0146167200262001$

Ehigie, B. O., Okang, G. O. \& Ibode, F. O. (2011). Mentoring and Organisational Behaviour. IFE Psycblogia. Supplement. 398-419.

Európai Unió Alapjogi Ügynökség (FRA) (2016). Oktatás: a romák belyzete 11 uniós tagállamban Felmérés a romákról - Középpontban az adatok. Luxembourg: Az. Európai Unió Kiadóbivatala. (URL: https://fra.europa.eu/sites/default/files/fra u ploads/fra-2014-roma-survey-dif-education hu. pdf) (Letöltés ideje: 2020. 10. 13.)

Falus I. (2003). A pedagógus. In Falus I. (szerk.). Didaktika. Elméleti alapok a tanítás tanulásához. Budapest: Nemzeti Tankönyvkiadó.

Fejes J. B. (2015). Célok és motiváció Tanulási motiváció a célorientációs elmélet alapján. Budapest: Gondolat.

Fényes H. (2009). Nemek szerinti iskolai eredményesség és a férfihátrány hipotézis. Magyar Pedagógia, 109(1), 77-101.

Gaál G. \& Jászi É. (2016). Pedagógus-mesterség. Líceum Kiadó, Eger.

Godó K., Ceglédi T. \& Kiss A. (2020). The Mentoring's Role among Alumni Students of István Wáli Roma College for Advanced Studies of the Reformed Church. CEJER, 2(1), 36-52. 
Godó K. (2021a). Az online mentorálás forradalma. A mentorálás offline és online minöségei a Tanitsunk Magyarországért Mentorprogramban. Kutatószemináriumi dolgozat

Godó K. (2021b). A reziliencia háttértényezôinek vizsgálata a debreceni egyetemisták körében. Szakdolgozat. Debrecen: Debreceni Egyetem.

Gyarmathy É. (2019). Psquichomeditáció. Budapest: Móra Könyvkiadó.

Hegedûs G. (2002). Motiváció és motiváltság. Világgazdaság. Menedzser melléklet.

Juhász J. (2015). A mentori munka a gyakorlatban. Budapest: OFI.

K. Nagy Emese (2015). KIP Könyv I-II. Miskolci Egyetemi Kiadó.

Klein, S., Benjamin, R., Shavelson, R. \& Bolus, R. (2007). The Collegiate Learning Assesment Facts and Fantasies. Evaluation Review, 31(5), 515-439. doi: $10.1177 / 0193841$ X07303318

Kö N., Pajor G. \& Szabó M. (2017). Motiváció. In N. Kollár K. \& Szabó É (Ed.). Pedagógusok pszichológiai kézikönyve II. kötet. Budapest: Osiris Kiadó.

Kovács K. (2015). Mentori kompetenciák, szerepek, tevékenységek egy vizsgálat tükrében. In Arató F. (Ed.). Horizontok, Pécsi Tudományegyetem. 89-99.

Markos V. (2019). Úton az aktiv állampolgári lét felé. Debrecen: PhD disszertáció

Mikrocenzus 2016 - 2. A népesség és a lakások jellemzőii. Budapest: KSH.

Nagy T. (2014). A tehetségesek mentorálása, rövid történeti áttekintés. In Gefferth É. (Ed.). Mentorálás a tehetséggondozásban. Budapest: MATEHETSZ. 11-18.

N. Kollár K. \& Szabó É. (2017). Pedagógusok pszichológiai kézikönyve II. kötet. Budapest: Osiris Kiadó.

Kram, K. (1985). Mentoring at Work. Foresman, Boston: Scott.

Kovács K. \& Fáyné Dombi A. (2015). Mentortanár szakos hallgatók mentorképe, mentorszerep- felfogása. In: Torgyik Judit (szerk.). Százarcú pedagógia. Szeged: SZTE JGYPK Tanító- és Óvóképző Intézet. 319-331.

Masten, A. S., M. Best, K. \& Garmezy, N. (1990). Resilience and development: Contributions from the study of children who overcome adversity. Development and Psychopathology, 2(4), 425-444. doi: 10.1017/S0954579400005812

Molnár N. (2014). Segítő szakmák felsőoktatási differenciálódása Magyarországon. In Kulturális és társadalmi sokszinüség a változó gazdasági környezetben. Gödöllő: Szent István Egyetem Enyedi György Region. 294-300.

Páskuné Kiss J. (2015). A pályaorientáció pszichológiai alapjai. Debrecen: Debreceni Egyetemi Kiadó.

Perjés I. \& Héjja-Nagy K. (2018). Tanulástámogatás a felsőoktatásban. Online mentorálási kézikönyv. Eger: Eszterházy Károly Egyetem.

Pearce, J., Down, B. \& Moore, E. (2008). Social class, identity and the 'good' student: negotiating university culture. Australian Journal of Education, 52(3), 257-271. doi: $10.1177 / 000494410805200304$

Pusztai G. (2004). Kapcsolatban a jövővel: Roma/cigány diplomások pályafutását támogató erőforrások. Valóság, 47(5), 69-84.

Pusztai G. (2009). A társadalmi tôke és az iskola. Budapest: Új Mandátum.

Raufelder \& A. Ittel (2012). Mentoring in der Schule: ein Überblick. Diskurs Kindheits- und Jugendforschung Heft, (2), 147-160.

Russel, J. E. A. \& Adams, D. M. (1997). The Changing Nature of Mentoring in Organizations: an Introduction to the Special Issue on Mentoring in Organizations. Journal of Vocational Behavior, 51(1), 1-14. doi: $\underline{10.1006 / j v b e .1997 .1602}$

Tízperc Iskolablog. Iskolába járni nem magánügy. Szerző: ismeretlen.

Szivák J. (1999). A kezdő pedagógus. Iskolakultúra, 4, 3-13. 